Integritas 4.2 (Fall 2014), pp. 1-21.

doi: 10.6017/integritas.v4i2p1

\title{
Widening Cultural Horizons in the Academy: Its Contribution to Catholic Identity
}

\author{
Katarina Schuth, O.S.F.
}

\begin{abstract}
Awareness and appreciation of the many cultures that constitute Church membership will enhance one's sense of Catholic identity. The notion of universality relates to beliefs at the heart of Catholicism, such as the oneness of the human family and respect for the life and dignity of every person. The more we know of the cultures of the "other" the more likely we are to understand their hopes and dreams, their joys and sorrows. In light of these foundational teachings, the mission of Catholic higher education should include programs that expand the cultural horizons of their students. This paper examines the significance of culture for the Church, and provides illustrations of how Catholic higher education institutions are developing cultural competence among their faculty and students.
\end{abstract}

\section{Introduction}

A few months ago, I participated in a seminar sponsored annually for many years by the J.S. Paluch Company to encourage vocations to the priesthood and religious life. The theme of the most recent event, "Vocation: From Local to Global Vision," highlighted the theme of the universal dimensions of the Church. The keynote address, by Rev. Thomas Rosica, C.S.B., English language assistant to the Holy See Press Office, emphasized ways in which Pope Francis has opened new horizons for the Catholic Church. ${ }^{\mathrm{I}}$ He related

1 Thomas Rosica's unpublished address, "The Franciscan Revolution of Tenderness," was delivered on

Katarina Schuth, O.S.F., holds the Endowed Chair for the Social Scientific Study of Religion at the University of St. Thomas (MN). Her areas of teaching and research include pastoral theology, the sociology of religion, and cross-cultural perspectives on religion and society. Sr. Schuth has published numerous books, chapters, and articles. She also serves on the advisory board for the Bernardin Center for Theology and Ministry at Catholic Theological Union, and is a charter member of the Catholic Common Ground Initiative. 
how "Pope Francis sees the world as his parish rather than a realm or classroom. Francis iterates this by the ease with which he communicates with his audiences." Moreover, Rosica asserted, "Pope Francis is challenging us to become 'the tender embrace of the Church' for all who are marginalized and on the fringes and on the frontiers of the society in which we live." Rosica explained that by articulating his openness to all people, the Pope challenges us to understand the truly universal dimensions of the people of God. He said:

In many ways Francis has become the world's leading source of moral authority because he combines personal charisma with the institutional authority of leading the world's largest Christian church, with more than I.2 billion followers in every corner of the planet. Catholicism is also the only world religion with its own diplomatic corps, as the Vatican is a sovereign state with bilateral relations with I80 nations. That gives the Church a unique platform to act as a voice of conscience in global affairs.

\section{It is incumbent on the academy to educate students in our colleges and universities to engage the world by acquiring knowledge of other cultures and peoples.}

This stance of Pope Francis, as articulated by Rosica, suggests that it is incumbent on the academy to educate students in our colleges and universities to engage the world by acquiring knowledge of other cultures and peoples. Thus from an educational perspective it follows that awareness and appreciation of the many cultures that constitute Church membership will enhance the sense of Catholic identity. Further, it relates to other beliefs at the heart of Catholicism, among them respect for the life and dignity of every person and the oneness of the human family that makes us responsible for one another. ${ }^{2}$ The more we know of the other-whatever their national, racial, ethnic, economic, or ideological differences - the more likely we are to understand their hopes and dreams, their joys and sorrows. In light of these foundational teachings, more and more Catholic institutions of higher education are providing programs and structures that expand the cultural horizons of their faculty and students.

As a matter of fact, the Church has always assigned great importance to the varied dimensions of cultural understanding, and so this paper presents in a nutshell aspects of the role of culture from its origins to the present time. It also provides examples of how Catholic colleges and universities have carried out their responsibilities of teaching

August 18, 2014. He is also the CEO of the Salt and Light Catholic Media Foundation of Canada.

2 See, for example, the U.S. bishops' articulation of the themes of Catholic social teaching: www.usccb. org/beliefs-and-teachings/what-we-believe/catholic-social-teaching/seven-themes-of-catholic-socialteaching.cfm. 
students to live in a diverse world. The paper begins with references to Sacred Scripture, showing how a cultural point of view was established by New Testament writers and gained pride of place over time. It relates several success stories of early evangelization efforts describing how attention to culture facilitated the spread of the faith. The close of the first part of the paper explores aspects of the documents of the Second Vatican Council and succeeding papal pronouncements that reveal the added weight given to inclusion of various cultural perspectives.

The second part of the paper concerns how Catholic higher education institutions are meeting the responsibility of promoting cultural understanding through curricular programs, field experiences, and service opportunities. The disposition of the faculty is a central element in furthering this approach by raising consciousness, as transmitted in their attitudes toward students, in the content of courses, and in recognition of the impact of cultural diversity. The indispensable role of faculty requires support, and so the role of leaders is considered as well. Concluding the paper are illustrations of how our institutions are developing cultural competence among students by incorporating relevant topics in courses, encouraging enrollment of international students, and offering a variety of opportunities that insert students into other cultures. A goal of these experiences is to break down cultural barriers and foster relationships among diverse peoples. Curricula and programs at both graduate and undergraduate levels are suitable for these involvements.

From the beginning it is helpful to note that the paper is not intended to show that international experiences function as a means of preparing students to become evangelizers or to serve as missionaries, though that may be a valuable side effect. Second, by highlighting the positive examples of ways the Church's message has been disseminated through intercultural endeavors, it is not meant to discount the unfortunate encounters that have stripped native cultures of their traditions. The intent of the paper is to demonstrate how international education properly executed enhances Catholic identity and changes hearts and minds through contact with those of other cultures, both on campus and through study abroad.

\section{A. Awareness of the Significance of Culture in Scripture and the Tradition}

The understanding of the Catholic Church as "universal" is a well-established fact and an article of faith. Universality, though, has several meanings: the Church is universal because of Christ's presence, because of her mission to the whole world, and because members are found in a wide array of cultures with varying expressions and practices. The first disciples showed clear evidence of attentiveness to cultural nuances. As they began the mission of spreading the Gospel, early evangelists carried on the tradition based on both their Jewish heritage and the particular group they were encountering. The Church continues to reinforce this understanding in numerous documents and pronouncements. 
I. Recognizing the role of culture in Sacred Scripture

Many passages in Sacred Scripture reveal how observant the writers were of their environment and of the lives of the people surrounding them. The texts of both testaments describe the beliefs, customs, practices, and social behaviors-in effect the culture of the people to whom they were addressing their message-and how these attributes affected their relationship with God and neighbor. More pertinent here is the New Testament, which provides direct admonitions to pay attention to the circumstances and diverse cultures that were part of the world in the early first century. Many passages illustrate how Jesus challenged his first followers and how intent he was on teaching his listeners to consider their everyday situation. He said to the crowds,

When you see [a] cloud rising in the west you say immediately that it is going to rain-and so it does; and when you notice that the wind is blowing from the south you say that it is going to be hot-and so it is. You hypocrites! You know how to interpret the appearance of the earth and the sky; why do you not know how to interpret the present time? (Lk I2:54-56; see also Mt I6:2-3). ${ }^{3}$

The passages in both Luke and Matthew are set in the context of Jesus proclaiming the Kingdom and calling his early followers to be faithful to his teachings. He admonished them to be in right relationships and to make right judgments based on those who were destined to hear his word. Each of the synoptic authors targeted a specific audience representing a particular community with Jesus' admonition in mind.

Numerous other references show how the disciples responded to Jesus' challenge to undertake evangelization with the goal of addressing the people in their cultural location. Saint Paul was particularly attuned to this precept in his approach to the first Christians. He saw his mission as intended for all: "I have become all things to all, to save at least some" (I Cor. 9:22). Paul excelled at grasping what it meant to acknowledge the context. In his speech at the Areopagus he stood up and said:

You Athenians, I see that in every respect you are very religious. For as I walked around looking carefully at your shrines, I even discovered an altar inscribed, 'To an Unknown God.' What therefore you unknowingly worship, I proclaim to you...it is he who gives to everyone life and breath and everything. He made from one the whole human race to dwell on the entire surface of the earth, and he fixed the ordered seasons and the boundaries of their regions, so that people might seek God, even perhaps grope for him and find him, though indeed he is not far from any one of us. For 'In him we live and move and have our being,' as even some of your poets have said, 'For we too are his offspring' (Acts I7:22-28).

Paul used the signs of "the Kingdom" as he acknowledged God's presence in what he discovered about the Greeks all around him: "you unknowingly worship, I proclaim to you" "he is not far from any one of us," "even some of your poets have said, "for we too are his offspring." Rather than denouncing them as false believers, he honored what was part of their culture and connected it to the teachings of Jesus about the Kingdom. 


\section{Throughout the Church's history, evangelizers had the greatest success in delivering the gospel message in cultural settings different from their own when they understood the new culture.}

These are a few illustrations of dozens, if not hundreds, of similar references in both testaments. Culture and context mattered right from the start.

2. Acknowledging the importance of culture in early evangelization

Throughout the Church's history, evangelizers had the greatest success in delivering the gospel message in cultural settings different from their own when they understood the new culture. These early messengers of the Good News held in common certain approaches and methods to reach the people in the societies they were entering. An essential requirement for connecting with new populations was establishing effective communication by learning their language. Evangelizers also studied other aspects of the culture so that they could adapt established symbols and practices and incorporate them in acceptable ways, thus creating a bridge to the new community. Peter's speech in the Acts of the Apostles reinforced this approach: "In truth, I see that God shows no partiality. Rather, in every nation whoever fears him and acts uprightly is acceptable to him" (Acts I0:34-35). Among many successful evangelizers, three outstanding exemplars embody the method: Saints Cyril and Methodius in their mission to the Slavonic peoples in the ninth century, and Matteo Ricci to the Chinese people in the sixteenth century. ${ }^{4}$

Cyril and Methodius were brothers, born with the names Constantine and Michael early in the ninth century to wealthy Christian parents of the noble class in Thessalonica in modern day Greek Macedonia. Both were well educated at the Imperial School of Constantinople-Constantine as a philosopher and Michael as a civil administrator. Even though they were successful in their secular careers, they were drawn to religious life. Constantine became a deacon and later a priest, while Michael entered a monastery and took the name Methodius. In 860, they were asked by the Byzantine emperor to join a delegation to the Khazars, on the Black Sea, for political purposes. Shortly after their return, Prince Rastislav of Moravia petitioned the emperor to send Christian missionaries to his nation. Constantine and Methodius were chosen. The brothers had become familiar with the culture and language as a result of having been raised in a region of Greek and Slavic speakers, and moreover their mother was likely a Slav. They realized

4 Among many sources dealing with Ss. Cyril and Methodius and Matteo Ricci, several focus attention on approaches to the cultures being evangelized: Joseph P. Fitzpatrick, S.J., "One Faith, Many Cultures: Historical Perspectives," International Papers in Pastoral Ministry, Vol. 1, No. 3 (November 1990) 1-15; Jeremy Clarke, "When West Meets East," America, Vol. 202 (May 10, 2010) 13-16; John W. O'Malley, "A Prophet of the New Evangelization," The Word Among Us (June 2013); Patricia Mitchell, "Making Disciples of All Nations," The Word Among Us (February 2010). 
that the Slavs did not have a written language, so before they began the mission, they resolved to develop a new script, Glagolitic, the precursor to Cyrillic. With the new script, the brothers translated the scriptures and the liturgy into Slavonic. During their first four years in Moravia, they preached and celebrated Mass using the Slavonic liturgy "and fostered religious Catholic practice adapted to the customs and way of life of the Slavic people. It provided the Slavic people with a deep and abiding sense of their identity." 5

The success of their mission created jealousy and suspicion among some Church leaders and so they went to Rome on their own, or perhaps were summoned by Pope Nicholas I. He died before the brothers' arrival, though, and was succeeded by Pope Adrian II, who questioned them about why they used the Slavonic liturgy since only Hebrew, Greek, and Latin had ever been used before. As a justification for the practice, Cyril cited the words of St. Paul: "Every tongue shall confess that Jesus Christ is Lord" (Philippians 2:II). The pope approved of their work and consecrated Methodius as bishop, and he later became an archbishop in Moravia. The use of the Slavonic books remained a controversy that lasted for centuries. A month before his death in Rome Constantine took monastic vows and the name Cyril.

Though the brothers were loved and honored by the Slavic people, controversy persisted through the years. Nonetheless, the Vatican supported their efforts, even to modern times. In I980, in his Apostolic Letter Egregiae Virtutis, ${ }^{6}$ Pope John Paul II named Cyril and Methodius co-patrons of Europe. In I985, he memorialized them again in the Encyclical Slavorum Apostoli (Apostles of the Slavs). ${ }^{7}$ When depicted together on icons they wear episcopal (Methodius) and monastic (Cyril) vestments, and are accompanied by books or scrolls bearing Cyrillic writing.

Matteo Ricci, an Italian Jesuit born in I552, was sent to China with other Jesuits in I583. Their approach to evangelization was based on their knowledge of the Scriptures as well as on their predecessors' methods that followed the example of Paul and others. Ricci perceived the deepest meanings of Chinese civilization and adjusted the Catholic faith to their life and culture. In writings about the Chinese mission, Ricci's method was described as follows: "He had the genius to attempt to adapt the Catholic faith to the life and culture of China in such a way that it would not disrupt the Chinese way of life, but give it a more creative fulfillment in the context of Catholic belief and practice." ${ }^{8}$ It took Ricci and his companions five years to learn Mandarin so that they could study the literary classics and other aspects of the culture that were important to the mission. Catholicism flourished as the Jesuits translated the Gospels into Chinese and developed a Chinese liturgy. Imagine the task of creating a dictionary that showed

5 Fitzpatrick, 4.

6 Pope John Paul II, Apostolic Letter Egregiae Virtutis (31 December 1980): Acta Apostolicae Sedis 73 (1981), pp. 258-262.

7 Pope John Paul II, Encyclical Slavorum Apostoli (2 June 1985), at http://w2.vatican.va/content/johnpaul-ii/en/encyclicals/documents/hf_jp-ii_enc_19850602_slavorum-apostoli.html.

8 Fitzpatrick, 6. 
the correspondence between the Latin alphabet and Chinese script!

Ricci, in his letters, spoke about his ministry as dedication and love of God:

I and all those who are here dream of nothing else day and night but the conversion of the Chinese. For this we have left our country and dear friends, and are dressed in the clothes and shoes of China. We speak, eat, drink, and dress in nothing but according to the manner of China. ${ }^{9}$

Ricci died in I6Io with Roman approval of his efforts, which were replicated for over Ioo years. Unfortunately, in I704, after other European priests came to China, they pleaded with the new Pope Clement XI to revoke the Chinese Rite, which was finally condemned by Pope Benedict XIV in I742, ending the Chinese mission. But fortunately in I9I9, Pope Benedict XV issued Maximum Illud, an encyclical that demanded respect for the cultures of the people to whom the Gospel was being preached. In I936, Pope Pius XI ended the condemnation of the Chinese Rites. Recognizing the wisdom of the approach of Ricci, in I982 Pope John Paul II commemorated the 40oth anniversary of his arrival in China by offering glowing praise for Ricci. Throughout Asia, the growth of Catholicism has been phenomenal, in part because of the freedom given to adapt to local cultures. In the twentieth century, the Church emphasized again its roots in cultural terms, no more clearly shown than in the documents of Vatican II, and also in endeavors related to the New Evangelization promoted by all popes from Paul VI onward.

\section{Beginning with Paul VI, every pope since then has deepened the perception of the Church as universal and embedded in the local cultures of the many nations where it is present.}

3. Appreciating the impact of culture in Vatican II and post-conciliar documents

References to culture are replete in the 16 documents of Vatican II, with the word "culture" used 9I times and "cultural" 34 times in the texts. ${ }^{\text {I0 }}$ Two especially important documents, sometimes referred to as the two pillars of Vatican II, the "Dogmatic Constitution on the Church" (Lumen Gentium) and the "Pastoral Constitution on the Church in the Modern World" (Gaudium et Spes) link the Church with the present situation of the world, as does the "Decree on the Church's Missionary Activity" (Ad Gentes Divinitus). The diversity of cultures and ways of thinking were evident since the "Council included a large number of bishops from the Third World, and the point of view of the churches of Asia, Africa, and Latin America," who "had a considerable impact on bishops from European and North American countries." ${ }^{\text {II }}$ The council fathers, along

9 Quoted by John O'Malley, "A Prophet of the New Evangelization."

10 By way of contrast, the word "culture" occurs only once in Vatican I documents.

11 Fitzpatrick, 447. 
with various experts and observers, represented the internationalization of the Church and the diversity of the cultures it embodied. ${ }^{\text {I2 }}$

Post-conciliar documents demonstrate the continuing emphasis on the cultural dimensions that were recognized during Vatican II. Beginning with Paul VI, every pope since then has deepened the perception of the Church as universal and embedded in the local cultures of the many nations where it is present. Documents on evangelization, such as Paul VI's I975 "Apostolic Exhortation on Evangelization” (Evangelii Nuntiandi) and John Paul II's I990 “On the Church's Missionary Mandate” (Redemptoris Missio), continued the emphasis. ${ }^{13}$ As they developed strategies for evangelization, many bishops' conferences and individual bishops explained the concept in terms of their local cultural situations.

a. Recognition of culture in documents of Vatican II

Expressions of diversity are reflected in virtually every document of Vatican II, but especially in Lumen Gentium (LG), one of the earliest documents, and Gaudium et Spes (GS), one of the latest. The second chapter of Lumen Gentium describes the "People of God" in inclusive terms:

God gathered together as one all those who in faith look upon Jesus as the author of salvation and the source of unity and peace, and established them as the Church that for each and all it may be the visible sacrament of this saving unity. While it transcends all limits of time and confines of race, the Church is destined to extend to all regions of the earth and so enters into the history of mankind. (LG 9). ${ }^{\mathrm{I}}$

In chapter seven, "The Pilgrim Church," the notion that the Church and the world are inextricably linked is reinforced:

However, until there shall be new heavens and a new earth in which justice dwells, the pilgrim Church in her sacraments and institutions, which pertain to this present time, has the appearance of this world...(LG 48 ).

The Church includes people from everywhere on earth and does not exist outside the living cultures.

Gaudium et Spes reinforces concepts introduced in Lumen Gentium by defining terms and formulating directives about cultural considerations. Even the themes of the opening paragraphs emphasize the connection between the Church and the world: solidarity of the Church with the whole human family (GS 2-3). The well-known opening sentences express the same sentiments:

12 Fitzpatrick, 449.

13 In the years following, John Paul II expanded on the theme in continental documents: Ecclesia in Africa, 1995; Ecclesia in America, 1999; and Ecclesia in Asia, 1999. The Pontifical Council for Culture added to the literature with "Toward a Pastoral Approach to Culture," Origins 29/5 (June 17, 1999): 65, $67-83$.

14 All citations of the documents from Vatican II are from the translations at the website of the Holy See, www.vatican.va. 
The joys and the hopes, the griefs and the anxieties of the men of this age, especially those who are poor or in any way afflicted, these are the joys and hopes, the griefs and anxieties of the followers of Christ. Indeed, nothing genuinely human fails to raise an echo in their hearts. (GS I).

To further deepen appreciation of the connection among all peoples,

this council can provide no more eloquent proof of its solidarity with, as well as its respect and love for the entire human family with which it is bound up, than by engaging with it in conversation about these various problems. The council brings to mankind light kindled from the Gospel, and puts at its disposal those saving resources which the Church herself, under the guidance of the Holy Spirit, receives from her Founder (GS 3).

In view of the openness of the council fathers to the plurality of cultures, a new awareness emerged about the universality of the Church, along with new cultural and ecclesial perceptions. Many commentaries point to the impact of culture on the council; of particular note are these exceptional works: five volumes on the History of Vatican II, ${ }^{15}$ What Happened at Vatican II, ${ }^{16}$ and Vatican II: Assessment and Perspectives. ${ }^{17}$ The extensive five-volume work edited by Alberigo and Komonchak allowed them to reference comments of council fathers from all over the world and to elaborate on their speeches, as well as to provide responses of both the fathers and observers to many of the themes and documents. Schillebeeckx, for example, summed up the discussion that focused on culture:

The slightly agitated tone that could be felt in various speeches of the bishops seems to have its origins in the fathers' realistic sense of concrete humanity and in the fact that the fathers of the council are preoccupied with what is happening in the world today and are asking themselves how the Church, as a Church with a messianic mission, ought to be engaged in this contemporary event...with how the Christian truth can become an 'event' in the world of today. ${ }^{18}$

The development and eventual approval of Lumen Gentium clearly expanded the interests of the Church ad extra as a renewing leaven for it. It concerned itself in a new way with the world. John O'Malley maintains that Vatican II attempted to do what no council before it had done:

It turned attention from what councils had always before been concerned with, internal Church affairs, to the world outside. It addressed concrete, contemporary issues and problems, such as world peace and a just socio-economic order. In all its drafts, moreover, it projected an image of the Church as a helpmate to all

15 Giuseppe Alberigo, ed., and Joseph Komonchak, English version ed., History of Vatican II, Five Volumes (Maryknoll, NY: Orbis Press, 1996 to 2006).

16 John O'Malley, What Happened at Vatican II (Cambridge, MA: Harvard University Press 2008).

17 Rene Latourelle, ed., Vatican II: Assessment and Perspectives, Three Volumes (New York, NY: Paulist Press, 1988 and 1989).

18 Alberigo and Komonchak, Volume 4, 328. 
persons of good will, whether Catholic or not, whether Christian or not, and as a beacon of hope for a better world. ${ }^{\text {I9 }}$

The notion that the Church was to be involved with the world was bolstered in Lumen Gentium, as it treated themes related to how "the people of God" were to live in society and fulfill their responsibilities to the world. The document emphasized the role of the laity in this task as it called them to witness through their secular activities to create human solidarity and a more just and peaceful world. The universal nature of the Church was specifically acknowledged:

Therefore, by their competence in secular training and by their activity, elevated from within by the grace of Christ, let them vigorously contribute their effort, so that created goods may be perfected by human labor, technical skill and civic culture for the benefit of all men according to the design of the Creator and the light of His Word. May the goods of this world be more equitably distributed among all men, and may they in their own way be conducive to universal progress in human and Christian freedom. In this manner, through the members of the Church, will Christ progressively illumine the whole of human society with His saving light. ( $L G$ 36)

The tenor of Lumen Gentium makes clear the connection among all human beings, regardless of race, ethnicity, location, or economic status. That association requires people of all nations to be aware of and understand those from all over the world-to know about other cultures.

\section{The task of the Church is to understand culture, which is to understand the world and respond more fully to its needs.}

To reinforce this view, in Vatican II: Assessment and Perspectives, the chapter most pertinent to this discussion is "The Contribution of the Council to Culture" by Hervé Carrier, which refers to the Council as a "cultural event." Cultural dimensions emerged, Carrier asserted, because of the quality and origins of the participants and their theological-historical vision. He discussed what the Council had to say about culture in four sections dealing with I) a modern definition of culture; 2) a call to cultural analysis; 3) the conciliar image of the world and the Church; and 4) the encounter with contemporary mentality. ${ }^{20}$ In his discussion, Carrier uses the definition of culture from Gaudium et Spes (53): “The word 'culture' in its general sense indicates everything whereby man develops and perfects his many bodily and spiritual qualities...." The task of the Church is to understand culture, which is to understand the world and respond more fully to its needs; that, says Carrier, means that culture "is always seen as the

19 O'Malley, 233.

20 Hervé Carrier, S.J., in Latourelle, Volume Three, "The Contribution of the Council to Culture," 442-465. 
context for theological reflection and pastoral projection." ${ }^{21}$

Carrier emphasizes the point that beyond Gaudium et Spes: "everything at the Council was concerned with culture, just as everything was concerned with theology." 22 As an example, he quotes from Sacrosanctum Concilium (27): "It is recommended that the gifts and characteristics of each culture should be carefully examined in order to see what can be assimilated into an authentic Christian liturgical practice." Carrier underscores the role of education, "the whole area of education is considered within a perspective of cultural development, with the aim of providing a well-rounded intellectual and spiritual formation for the young, making use of advances in psychology and teaching methods." ${ }^{23}$ He explains that culture as understood by the council is found in a great variety of contexts, among them in schools and universities related to the human and spiritual formation of priests, religious, and lay people. Fortunately, the council's recognition of the worldwide character of the Church coincided with expanded means of communication and travel, making it possible for educational institutions to maximize opportunities to expose students to other cultures.

b. Recognition of culture since Vatican II

Since Vatican II, every pope has continued to respond to the cultural differences in the many situations in which the Church is present. Pope Paul VI experienced on a daily basis the universality and variety of Catholics around the world during the council and so it is no surprise that after the council he set forth principles in his Apostolic Exhortation, Evangelii Nuntiandi (EN) ${ }^{24}$ that have guided his successors in their approach to cultures. He made the point that the Church must preach the Gospel "in ever wider geographic areas or to ever greater numbers of people," which affects the "criteria of judgment, determining values, points of interest, lines of thought, sources of inspiration and models of life, which are in contrast with the Word of God and the plan of salvation" (EN I9). Referring to Gaudium et Spes, he says that what matters is to evangelize culture and cultures in vital and deep ways, "always taking the person as one's starting-point and always coming back to the relationships of people among themselves and with God." Though independent of cultures, the Gospel and evangelization are not necessarily incompatible with them; rather they are capable of permeating them all without becoming subject to any one of them, and "building up of the kingdom cannot avoid borrowing the elements of human culture or cultures" (EN 20).

In clearest terms, Paul VI describes the relationship between evangelization and culture and the necessity of using appropriate methods in order to reach people:

The obvious importance of the content of evangelization must not overshadow the importance of the ways and methods. This question of "how to evangelize"

21 Carrier, 455. See also paragraphs 53 to 62 of Gaudium et Spes, "Proper Development of Culture."

22 Carrier, 456.

23 Carrier, 457.

24 Paul VI, Evangelii Nuntiandi, Apostolic Exhortation, December 8, 1975, online at www.vatican.va. 
is permanently relevant, because the methods of evangelizing vary according to the different circumstances of time, place and culture, and because they thereby present a certain challenge to our capacity for discovery and adaptation. On us particularly, the pastors of the Church, rests the responsibility for reshaping with boldness and wisdom, but in complete fidelity to the content of evangelization, the means that are most suitable and effective for communicating the Gospel message to the men and women of our times (EN 40).

Carrying forward the intentions of Paul VI, in I982 John Paul II created the Pontifical Council for Culture. His worldwide and frequent travels heightened consciousness of how truly universal the Catholic Church is and how important it is to be aware of the cultural situation of each local church. In his 2004 address to the New England bishops during their ad limina visit, the pope approached the concept of culture from several angles. ${ }^{25}$ He recognized the fundamental challenge of bringing about a fruitful encounter between the Gospel and any new culture. He became more specific by recommending distinctive actions that should flow from the situation in the U.S. He referenced St. Paul's letter to the Ephesians, "through the gift of God we have become 'ministers of the Gospel' and received the grace 'to preach to the nations the unfathomable riches of Jesus Christ." ${ }^{26} \mathrm{He}$ then tells the bishops that he wishes "to consider some particular concerns facing the Church in the United States as she carries out her duty to proclaim the Gospel and lead all people to the fullness of faith, freedom, and salvation in Christ." ${ }^{27}$ He points out the importance of discerning profound spiritual needs and aspirations of U.S. culture as well as encouraging missionary activity by making "every effort to revive this powerful manifestation of solidarity with the universal Church." ${ }^{28}$ The goal is to overcome misunderstandings and build peace in order to renew the whole Church.

Early in his pontificate, Pope Francis promulgated his first Apostolic Exhortation Evangelii Gaudium, in which he forwarded the universal themes of his predecessors. In dealing with the world, the pope calls for all "to enter fully into the fabric of society, sharing the lives of all, listening to their concerns, helping them materially and spiritually in their needs, rejoicing with those who rejoice and weeping with those who weep." ${ }^{29}$ He continues: "Whenever we encounter another person in love, we learn something new about God. Whenever our eyes are opened to acknowledge the other, we grow in the light of faith and knowledge of God"(272). These encouraging words of Pope Francis promote the attitude that by getting to know "the other" we are able to care for them and respond in a way that is fruitful for their welfare and our own. It seems that the entire

25 John Paul II, "The Importance of the Evangelization of Culture," Origins, Sept. 16, 2004, Vol. 34: No. 14, 217, 219-220. with the exercise of his power. To me, the very least of all the holy ones, this grace was given, to preach to the Gentiles the inscrutable riches of Christ..."

27 John Paul II, 217.

28 John Paul II, 219.

29 Pope Francis, Apostolic Exhortation Evangelii Gaudium 227 (2013), online at www.vatican.va. 
tradition of the Church leads naturally to engagement. The task of Catholic colleges and universities, then, is to enable students to participate in opportunities that will promote interaction with other cultures. Many institutions are finding ways to meet the challenge, as described below.

\section{B. Promotion of Cultural Understanding in Colleges and Universities: Its Impact on Catholic Identity}

Having established the longstanding tradition of the Catholic Church's awareness of cultural manifestations in its evangelizing efforts, several questions deserve consideration as we explore the role of education in promoting cross-cultural understanding. What are some effective methods of providing knowledge and experiences in Catholic colleges and universities about these topics and themes? What do the Church and Catholic higher education institutions hope for as outcomes that result from teaching students about other cultures and peoples? Paramount values are:

- to foster appreciation of people from diverse backgrounds and locales and

- to avoid the consequences of a narrow vision of humanity.

Positive results will be observable in the practice of virtues such as respect, kindness, and compassion, and elimination of vices and evil actions such as hatred, exploitation, violence, and degrading treatment of those whose value is not recognized. In a phrase, it is to create justice, harmony, and peace on earth. Useful methods of achieving these high purposes begin with administrators and faculty who believe in the importance of teaching about and experiencing the world beyond the local context of students. Students, in turn, must choose to involve themselves in classes and programs to expand their horizons by taking advantage of opportunities offered in their institutions. Examples of these good practices for both faculty and students are abundant and are discussed in what follows.

\section{Effective educational practice requires teachers to be aware of the global interconnectedness and interdependence that have brought a wide variety of students to our campuses.}

I. Raising consciousness of faculty about the role of cultural diversity in teaching and learning

Regardless of a school's location, level of students, or type of classroom situations, cultural diversity is present in every setting and in many different forms. Especially in recent years, faculty and researchers have voiced their conviction that effective educational practice requires teachers to be aware of the global interconnectedness and interdependence that have brought a wide variety of students to our campuses. To be responsive to their needs, several levels of engagement are necessary. The commitment 
may be in the form of curricular attention to cross-cultural issues, for example, through the study of other religions, and through opportunities for international learning experiences. Another way of showing receptiveness to student needs is to foster classroom interaction that encourages positive relationships with students from differing backgrounds.

In Discussion as a Way of Teaching, Stephen Brookfield and Stephen Preskill devote an entire chapter to cultural diversity in the classroom. Throughout the book they recognize diversity as a strength and not a liability toward successful learning..$^{\circ}$ Parker Palmer, in his writings, is sensitive to the outlook of all students as they involve themselves in the educational process. Palmer's The Courage to Teach is especially rich in its exploration of the importance of community in the classroom, which entails knowing, teaching, and learning in situations that include faculty and students of varied backgrounds..$^{3}$ Understanding and respecting the distinctive situations of students is an ideal way of modeling behaviors that are important to favorable reception of the diversity students will encounter in their lives. Colleges and universities have the responsibility to arrange for faculty development sessions that provide ways to approach the complex task of facilitating interaction among students.

Perhaps most crucial to implementing effective faculty development in the area of international education is the backing of institutional leaders. Ideally they will provide both funding and moral support, indicating their understanding and commitment to the value of such an education. The following excerpt from the address at the opening convocation for faculty by President Julie Sullivan at the University of Saint Thomas illustrates the point:

How do interdisciplinary inquiry and intercultural understanding contribute to preparing students for the contemporary world?

The contemporary world is becoming increasingly interconnected. There are fewer and fewer single discipline problems and even fewer single country problems. Our biggest challenges are interdisciplinary and global. We must prepare our students to be connectors, to look beyond boundaries and across silos to find synergies and solutions. We also must prepare our students to engage the world; to be global citizens who effectively make human connections in ways that demonstrate understanding, empathy, and respect.

I expect our curriculum to become more integrated and emphasize interdisciplinary approaches and diverse perspectives. There will be a greater emphasis on multidisciplinary and thematic teaching and research. ${ }^{22}$

30 Stephen D. Brookfield and Stephen Preskill, Discussion as a Way of Teaching: Tools and Techniques for Democratic Classrooms (San Francisco, CA: Jossey-Bass Publishers, 1999), 127-150. CA: Jossey-Bass Publishers, 1998), 89-161.

32 President Julie Sullivan: Remarks at the Opening Faculty Convocation, University of St. Thomas, September 3, 2014. 
Higher education institutions in general have many resources to assist faculty in expanding their expertise related to intercultural concerns, but commitment to implementation depends greatly on the encouragement of leaders. Catholic colleges and universities have additional incentive and unique means of aiding faculty because of their identity as participants in a worldwide religious organization. In perusing the websites of Catholic schools, it is obvious that many are invested in supporting cultural understanding on their campuses for both faculty and students. Examples of well-developed international programs from Catholic institutions point to an immense variety available to students. Commonly, many schools have provided more extensive programming in recent years and some for the first time in just the past quarter century. A short synopsis of representative programs from among those involved in the Boston College Roundtable illustrates the variety and extent of offerings on campuses and opportunities for students studying abroad.

- Georgetown University, through its Office of Global Education, sends approximately 900 students abroad to earn academic credit in more than 40 countries. Students have the opportunity to study abroad all over the world and may choose a university-sponsored program or an independent program, or they may matriculate directly into a foreign university. They may also apply to one of three Georgetown centers overseas: Villa Le Balze in Florence, Italy; the McGhee Center for Eastern Mediterranean Studies in Alanya, Turkey; or the School of Foreign Service in Doha, Qatar.

- Boston College, through its Office of International Programs, offers more than I40 programs around the world on six continents, in virtually every discipline. All study abroad is considered to be integral to a comprehensive and holistic undergraduate experience. Students can select semester and full-year study or approved external programs. They gain skills and knowledge that help them become more globally competent and prepared for post-graduation career opportunities.

- Villanova University, through its Office of International Studies, encourages students to consider the many options available for study abroad, with goals of exposing students to the impact of globalization, fostering respect for diverse viewpoints, and developing an understanding of different cultures and backgrounds. Formats include summer intensive language programs in Europe and Jerusalem and many opportunities in countries ranging from Kenya, England, and Australia to Denmark, Mexico, Ecuador, and Costa Rica for summers or entire semesters.

- Santa Clara University, through its Global Engagement Office, provides leadership, coordination, strategic planning, and resources for the internationalization of the campus. Santa Clara offers study abroad programs for every major and on every continent except Antarctica. These opportunities to foster multicultural engagement and global understanding provide students 
with settings where they may explore and broaden their horizons and develop a deeper understanding of world cultures. Each program is designed to help students build a sense of independence and confidence.

\section{University of St. Thomas}

Given the limitations of this paper, as well as greater availability of information and extensive programming at UST, I will expand on examples related to faculty development in our setting. ${ }^{33}$ Faculty grants intended to broaden the involvement of faculty are commonly available, sometimes through funds provided by a particular school and at other times through outside sources of funding. At least two types of institutionally based grants-for travel and for seminars-are ordinarily available at UST. They are administered in conjunction with the Office of Academic Affairs through the International Education Center (IEC). The purpose of the travel grant "is to defray the cost of international travel that is intended to help UST faculty internationalize their teaching and research." Proposals must focus on one or more of the following:

- internationalize an existing UST course, or develop a new course with international focus;

- develop a new course or program to be taught outside the United States; and,

- undertake research that has an international focus. ${ }^{34}$

Funding is also available for the International Faculty Seminar Grant program sponsored by the Council of International Educational Exchange. The purpose of this type of grant is "to assist faculty in gaining international experience in order to internationalize their teaching, research, or both, and, to explore opportunities for international programming."

Institutional funding is provided for educational offerings through other organizations and institutions as well. These programs are intended for both faculty enrichment and broader purposes such as community development. One example is a seminar offered in conjunction with the Council on International Educational Exchange (CIEE): "Intercultural Accommodation, Integration, or Assimilation? An Encounter and Exchange with Minneapolis's East African Immigrant Community." The purpose of the seminar is to "explore and analyze the complex and multi-directional processes of community adaptation occurring when new arrivals introduce, and existing residents respond to, distinct cultural values, experiences, and practices as the new immigrants gain a foothold in contributing to local social and economic development." Besides enriching faculty, community engagement often leads to internships and service opportunities for students as well.

Attendance at the Standards of Good Practice Institute, "Curriculum, Teaching and Education Abroad," sponsored by the Forum on Education Abroad at the University of

33 I am indebted to Dr. Dennis Hart, Executive Director of the International Education Center (IEC), and Sarah E. Spencer, Director of Study Abroad, at the University of St. Thomas, who have provided information for this report.

34 Published by the Center for Faculty Development in the Synergia Newsletter, September 14, 2014. 
Minnesota, is also available. The offering covers curriculum, pedagogy, and teaching in the education abroad field. "This Standards Institute is dedicated to identifying and understanding an array of approaches to curriculum design and teaching in education abroad, and assisting participants to understand how to develop and improve their own education abroad curricula and enhance disciplinary and interdisciplinary teaching."35

As St. Thomas focuses on becoming a comprehensive urban university with "interdisciplinary approaches and diverse perspectives" and on educating an increasingly diverse student population, faculty are called upon to be prepared to teach students from a range of cultural and educational backgrounds. Toward this end, short-term learning opportunities are offered, such as a forum on "Understanding the International Student Experience." The central question on this particular topic was, What's one thing you can do to make your classroom more inclusive for international students? Its focus on the academic challenges faced by international students in the American classroom commenced with a student panel moderated by a communications and journalism professor from China. Students from India, Saudi Arabia, Taiwan, Vietnam, and Zimbabwe shared thoughts on strategies faculty can use to address these challenges when teaching in a culturally diverse classroom. They suggested ways of being inclusive in discussions, using examples from a variety of cultures, avoiding stereotypes, and, not surprisingly, simply caring about them. In cooperation with the Center for Faculty Development, the International Education Center has offered similar programs and useful handouts that treat topics such as language preparedness, understanding accents, instructional strategies, managing conflict, and developing trust.

More than 250 UST faculty have taught abroad and more than 300 have been 'globally engaged' in different ways with other countries. They have arranged study abroad opportunities in more than 50 countries. Departments with high levels of participation include Engineering, Law, Business, Theology, Catholic Studies, Biology, Communications, and Journalism. Curriculum integration is achieved by developing materials for "Major Advising for Study Abroad." Fifteen disciplines have created such protocols..$^{6}$ These few examples represent the types of faculty development programs and the numbers of faculty involved.

2. Opportunities for increasing cultural awareness and competence among students Advances in transportation and communication have brought the world to our doorstep. As boundaries grow more permeable and as immigration and migration expand, the need for understanding and accepting those with cultural backgrounds different from our own becomes more urgent. The Church has been in the forefront of encouraging understanding and compassion for others, in part because it is comprised of people of every race and nation, all part of the Body of Christ. Given the interdependent

35 University of St. Thomas Website: www.stthomas.edu/iec/ and http://studyabroad.stthomas.edu/.

36 These majors are: Biology, Business, Communication and Journalism, Engineering, English, French, Global Health, International Business, Justice and Peace Studies, Political Science, Psychology, Sociology, Spanish, and Women's Studies. 
world that current graduates will enter, colleges and universities need to change the content and methods of education. As noted above, in recent years most institutions have provided some form of global interaction, including exchange programs, affiliate programs, and internships abroad. The extent of participation varies, but many Catholic institutions require students to broaden their horizons by gaining knowledge and experience worldwide.

In its efforts to increase cultural understanding, UST has offered some specialized programs since the early I970s, but since I99I has vastly expanded its international efforts. At that time, almost 25 years ago, a five-year plan served as a framework and catalyst for expansion of international activities, which were coordinated by the International Education Center. The center was involved in organizing strategies across divisions and also establishing an admissions office and other support services for international students. ${ }^{37}$ Within a short time, more than 250 faculty from across the university were involved annually teaching abroad. The rapid expansion of activities led to an oversight, review, and support committee to approve all off-campus programs. Moreover, participating faculty were required to integrate academic coursework, intercultural learning, and onsite activity.

The commitment of both faculty and administrators is indispensable in order to achieve widespread cooperation and participation. Many of the schools and colleges sponsor ongoing international programs and continue development of others. Some examples of programs arranged by faculty for students to take advantage of are as follows:

- The College of Arts and Sciences offers a great variety of undergraduate study abroad programs, both during January terms and full semesters. As an example of the latter, undergraduates may participate in the Catholic Studies Semester, attending the Pontifical University of St. Thomas Aquinas in Rome, where they study Catholic social thought, art and architecture, theology, philosophy, and Italian language. Also, the Theology Department has established exchanges with Dokuz Eylul University in Turkey. The Geology Department sponsors desert field research in Patagonia and Mongolia.

- The School of Divinity (Saint Paul Seminary) requires its Master of Divinity students to participate in study abroad in the Holy Land, Rome, and London as well as in culture and language programs in Venezuela and Mexico.

- The School of Social Work is part of a consortial effort with Io other Minnesota schools offering an undergraduate Social Work program in Cuernavaca, Mexico, with each semester led by a faculty member from a member institution.

- The School of Engineering offers an undergraduate course on Architecture in Rome in January and has identified universities in Spain, England, and Australia where students may take engineering courses for a semester.

37 Information on the international programs at the University of St. Thomas was provided by Ann C. Hubbard and Sarah E. Spencer: "Local-Global: A Full Circle of Community Engagement," Nomination Essay for the Simon Award for Campus Internationalization, 2010. 
- The Opus College of Business, with nearly 40 percent of the total St. Thomas undergraduate body, is proportionately represented in the percentage of students who study abroad; for example, at London Business Semester, offered each fall for 50 undergraduates. Among many other programs, faculty have established relationships with Tamkang University in Taiwan and study abroad programs with the University of Caen Basse-Normandie, France, and the University of Siena, Italy.

- The School of Law offers a collaborative program in Rome each summer with Villanova University. Two faculty from each university teach a course. Law faculty are working to establishing a variety of partnerships in India and China, both to recruit students to UST and send students to those countries.

- The College of Applied and Professional Studies requires a study abroad capstone course in Africa as part of its International Leadership Master of Arts degree.

- The Honors Seminar offers "sections on preparing for an international experience," by incorporating intercultural theory with travel literature for students studying abroad for a semester.

A Global Scholars Certificate recognizing "Intercultural Development" is soon to be implemented. Students studying abroad for a semester start the program before they depart and finish upon their return to campus.

Availability of programs like these has resulted in tremendous growth in off-campus study-in numbers of students as well as in programs and destinations. Over a I,০০০ undergraduate students take part each year in I48 international programs, recently averaging about 60 percent of the student body, and resulting in top ro rankings in the IIE Open Doors Surveys almost every year. For many years, approximately 50 percent of students have studied abroad by the time they graduate. ${ }^{38}$ Given the location of UST (and its reputation for harsh winters), the enrollment of international students, though relatively small, is quite remarkable and gradually increasing; nearly 500 students from over 50 countries attend UST and the number is growing each year.

The direct global engagement has impacted the home curriculum, academic research, and publishing as well. Faculty developed new courses such as Global Perspectives on Gender, Cross-Cultural Perspectives on Religion in Society, Women in Zones of Conflict:

38 The international experiences of one extraordinary student offer an example of the benefits derived from off-campus studies. Over her four-year enrollment at UST, Sarah Farnes spent each January interim abroad: in Poland, Ukraine, Belarus, and Lithuania to study Comparative Politics; in New Zealand to study Environmental Policy and Sustainable Development; in Turkey to study Islam and its influence on Turkey; and again in Poland to study John Paul II in his Polish context. At another time she led university students on a service immersion trip to Guatemala. After graduation she interned with the Holy See Mission to the United Nations. The following year she received a fellowship to participate in an interreligious studies program at the Angelicum in Rome, which included a trip to the Holy Land. At present she works with students from many cultures and situations who need special attention to reach their potential. 
Latin America, and West Africa: Society in Transition. Faculty have adjusted on-campus core courses and pedagogies by integrating international experiences. For example, they incorporated Islamic architecture and design into the mathematics curriculum, introductory sociology added societal patterns from Mali, Ghana, and South Africa, and the MBA program expanded their courses in Investments with models from Hong Kong and other Asian countries.

Beyond courses, faculty engage the global dimension of studies in several ways. Some have transformed their scholarship agendas, including new publications, such as the book Global Families, and book chapters, such as "Thinking about a Postcolonial Return to Indigenous Justice in Africa." Faculty often refocus their research after teaching abroad. For example, one professor moved from canonical Romantic drama to dramatic representations of the Greek War of Independence while another professor looked toward international education and the impact of study abroad on the development of cross-cultural sensitivity, ethical and moral reasoning, and sustainability. After teaching a course in Egypt and securing local artists to provide the core of guest lecturers, a professor in Theater created three Minnesota-Middle East documentaries, including an artistic response to 9/II addressing cross-cultural misunderstanding between Arabs and Americans. All of these endeavors are changing the vision and focus of the campus from Midwestern to global.

\section{Conclusion}

The purpose of this paper has been to demonstrate how creating greater cultural understanding among faculty and students on our campuses enhances an important aspect of Catholic identity. The universal nature of the Catholic Church and its commitment to incorporating all cultures and peoples corresponds with the response of Catholic colleges and universities to educate their students to appreciate and respect the many peoples that constitute Church membership. Our institutions have taken responsibility for developing programs that introduce students to other cultures, especially through study abroad programs and through interaction with international students studying at our home institutions. The support of institutional leaders and the participation of faculty have made possible these encounters.

The mere existence of these programs does not guarantee success in the desired outcomes: respect for the life and dignity of every person and an understanding of the oneness of the human family. These values, if adopted, ensure that each student grows in the willingness to be responsible for others, whatever their culture and origins. Faculty need to make certain that international studies are not just occasions for touristlike travels. For a fruitful encounter to take place, preparation is essential. Experiences in the field must be designed to truly grapple with the situation existing at the destination. It means studying the entire background of the host country, its history and lifestyle, its values and religions, its economy and politics. Attention also must be given to students who cannot, or choose not, to participate in opportunities to become more globally sensitive; faculty need to monitor any negative classroom behavior toward diversity, 
especially in interaction with international students. Underpinning knowledge, attitudes about "the other" must be shaped in a way that embraces Catholic values, especially respect for the dignity of each person.

These suggestions, stated in the form of recommendations, are as follows:

- Focus the experience on learning: be certain that international studies are more than occasions for tourism.

- Preparation is essential. Study ahead of time the background of the host country, its history and lifestyle, its values and religions, its economy and politics.

- Design experiences in the field that grapple with the situation existing at the destination.

- Monitor on-campus classroom activities: be aware of negative speech and behavior directed toward students from other countries.

- Shape attitudes that embrace Catholic values: respect the dignity of each person, safeguard self-respect, and promote international solidarity.

The desired effects of international engagement include the following:

- Increase capacity for growth in awareness of the universal nature of the Catholic Church and what it values, and progress in understanding the meaning of Catholic identity.

- Create an impact on the home curriculum, academic research, and publishing through direct engagement with other countries.

- Develop new courses, new pedagogies, and new contacts shaped by international involvement.

- Provide benefits for students, such as broader relationships, enhanced employment opportunities, and deeper understanding of the world, derived from participation in international programs.

With these conditions, "Widening Cultural Horizons" will truly contribute to the Catholic identity of our institutions. 
